\title{
Taxonomic study of Halorubrum distributum and proposal of Halorubrum terrestre sp. nov.
}

Correspondence

Antonio Ventosa

ventosa@us.es

\author{
Antonio Ventosa, ${ }^{1}$ M. Carmen Gutiérrez, ${ }^{1}$ Masahiro Kamekura, ${ }^{2}$ \\ Irina S. Zvyagintseva ${ }^{3}$ and Aharon Oren ${ }^{4}$ \\ ${ }^{1}$ Department of Microbiology and Parasitology, Faculty of Pharmacy, University of Sevilla, \\ 41012 Sevilla, Spain \\ ${ }^{2}$ Noda Institute for Scientific Research, 399 Noda, Noda-shi, Chiba-ken 278-0037, Japan \\ ${ }^{3}$ Institute of Microbiology of the Russian Academy of Sciences, 117811 Moscow, Russia \\ ${ }^{4}$ Division of Microbial and Molecular Ecology, Institute of Life Sciences and the Moshe Shilo \\ Minerva Center for Marine Biogeochemistry, The Hebrew University of Jerusalem, \\ 91904 Jerusalem, Israel
}

In the course of a study of extremely halophilic microorganisms from saline soils, Zvyagintseva \& Tarasov (1987) proposed the species Halobacterium distributus, based on the features of four strains (designated $1 \mathrm{~m}^{\mathrm{T}}, 4 \mathrm{p}, 13$ and 32). This name was validly published and corrected to Halobacterium distributum (Zvyagintseva \& Tarasov, 1989). The strain designated as the type strain of this species is strain $1 \mathrm{~m}^{\mathrm{T}}$, deposited as VKM B-1733 ${ }^{\mathrm{T}}$ (Zvyagintseva \& Tarasov, 1989). Two almost-simultaneous studies (Kamekura \& Dyall-Smith, 1995; McGenity \& Grant, 1995) showed that most species that were previously assigned to the genus Halobacterium were not related to Halobacterium salinarum, the type species of this genus, and they were placed in the novel genus Halorubrum (McGenity \& Grant, 1995). On the basis of $16 \mathrm{~S}$ rRNA gene sequence comparison, Halobacterium distributum was also included in the genus Halorubrum, as Halorubrum distributum (Oren \& Ventosa, 1996).

Zvyagintseva et al. (1996) showed that the features of strain $1 \mathrm{~m}^{\mathrm{T}}$ were different from those of the other three strains that were assigned to the species Halorubrum distributum and they proposed strain $4 \mathrm{p}(=\mathrm{VKM} B-1739)$ as the new type strain of Halorubrum distributum. As this proposal was not in accordance with the rules of the International Code of Nomenclature of Bacteria (Lapage et al., 1992), Oren

The GenBank/EMBL/DDBJ accession number for the 16S rDNA sequence of Halorubrum terrestre strain VKM B-1739 ${ }^{\top}$ is $A B 090169$. et al. $(1997 \mathrm{a})$ confirmed strain $1 \mathrm{~m}^{\mathrm{T}}\left(=\mathrm{VKM} \mathrm{B}-1733^{\mathrm{T}}=\right.$ JCM $9100^{\mathrm{T}}$ ) as the type strain of Halorubrum distributum and suggested that an exhaustive study should be carried out in order to 'describe and validate a new species of Halorubrum and include a full phenotypic characterization', and to propose (preferably) strain $4 \mathrm{p}(=\mathrm{VKM} \mathrm{B}-1739)$ as its type strain.

In the present paper, we study in detail the type strain of Halorubrum distributum, a species that has not been well characterized phenotypically, as well as the other strains that were previously assigned to this species; we describe these as a novel species, for which we propose the name Halorubrum terrestre sp. nov.

Strains used in this study are shown in Table 1. Halorubrum distributum VKM B-1733 ${ }^{\mathrm{T}}$ and the other four strains (VKM B-1739, VKM B-1916, VKM B-1954 and VKM B-2151) were isolated from saline soils (Zvyagintseva \& Tarasov, 1987). Reference strains are type strains of species that belong to different halobacterial genera. They were cultured in a medium with a final concentration of approximately $25 \%$ salts and $0.5 \%$ yeast extract (Difco). The $\mathrm{pH}$ was adjusted to $7 \cdot 5$ with $1 \mathrm{M} \mathrm{KOH}$ (Torreblanca et al., 1986). Incubation was carried out at $37^{\circ} \mathrm{C}$ in an orbital shaker at 200 r.p.m. For phenotypic characterization, we followed the Minimal Standards for Description of New Taxa in the Order Halobacteriales (Oren et al., 1997b). The tests performed are 
Table 1. DNA $G+C$ contents and levels of DNA-DNA relatedness between Halorubrum distributum VKM B-1733' ${ }^{\top}$, strain VKM B-1739 and other related halobacterial strains

Hybridization of strains VKM B-1733 ${ }^{\mathrm{T}}$ and VKM B-1739 with the following strains was $<20 \%$ : Halobacterium salinarum DSM $3754^{\mathrm{T}}$, Haloarcula vallismortis ATCC $29715^{\mathrm{T}}$, Haloarcula argentinensis ATCC $700875^{\mathrm{T}}$, Haloarcula hispanica ATCC $33960^{\mathrm{T}}$, Haloarcula japonica JCM $7785^{\mathrm{T}}$, Haloarcula marismortui ATCC $43049^{\mathrm{T}}$, Haloarcula quadrata DSM $11927^{\mathrm{T}}$, Halomicrobium mukohataei DSM $12286^{\mathrm{T}}$, Haloferax volcanii NCMB $2012^{\mathrm{T}}$, Haloferax denitrificans DSM $4425^{\mathrm{T}}$, Haloferax gibbonsii ATCC $33959^{\mathrm{T}}$, Haloferax mediterranei ATCC $33500^{\mathrm{T}}$, Haloferax lucentense JCM $9276^{\mathrm{T}}$, Halobaculum gomorrense DSM $9297^{\mathrm{T}}$, Haloterrigena turkmenica JCM 9743, Natrialba asiatica JCM $9576^{\mathrm{T}}$ and Halococcus saccharolyticus ATCC $49257^{\mathrm{T}}$.

\begin{tabular}{|c|c|c|c|}
\hline \multirow[t]{2}{*}{ Source of unlabelled DNA } & \multirow[t]{2}{*}{$\begin{array}{c}\mathrm{G}+\mathrm{C} \text { content } \\
(\mathrm{mol} \%)\end{array}$} & \multicolumn{2}{|c|}{$\begin{array}{l}\text { Relatedness (\%) with } \\
{ }^{3} \text { H-labelled DNA from }\end{array}$} \\
\hline & & VKM B-1733 ${ }^{T}$ & VKM B-1739 \\
\hline Halorubrum distributum VKM B-1733 ${ }^{\mathrm{T}}$ & $63 \cdot 9$ & 100 & 55 \\
\hline Strain VKM B-1739 & $64 \cdot 4$ & 63 & 100 \\
\hline Strain VKM B-1916 & $64 \cdot 9$ & 60 & 98 \\
\hline Strain VKM B-1954 & $64 \cdot 6$ & 65 & 95 \\
\hline Strain VKM B-2151 & $64 \cdot 2$ & 25 & 99 \\
\hline Halorubrum saccharovorum ATCC $29252^{\mathrm{T}}$ & $64 \cdot 3^{\star}$ & 32 & 38 \\
\hline Halorubrum coriense JCM $9275^{\mathrm{T}}$ & $66 \cdot 3^{*}$ & 31 & 18 \\
\hline Halorubrum lacusprofundi DSM $5036^{\mathrm{T}}$ & $65 \cdot 3^{*}$ & 45 & 5 \\
\hline Halorubrum sodomense ATCC $33755^{\mathrm{T}}$ & $66 \cdot 0^{*}$ & 20 & 21 \\
\hline Halorubrum trapanicum NCIMB $13488^{\mathrm{T}}$ & $64 \cdot 3$ & 33 & 6 \\
\hline
\end{tabular}

${ }^{*}$ Data from Grant et al. (2001).

included in the species description. The methodology used has been described previously (Torreblanca et al., 1986). Unless otherwise indicated, tests were carried out in media that contained $25 \%$ salts, at $\mathrm{pH} 7 \cdot 5$ and incubated at $37^{\circ} \mathrm{C}$.

Polar lipids were extracted with chloroform/methanol as described previously (Kamekura, 1993). One-dimensional TLC was done by using Merck HPTLC $10 \times 20 \mathrm{~cm}$ plates, silica gel 60 (code 1.05641) or Aldrich $20 \times 20 \mathrm{~cm}$ plates (code Z12271-8) in a solvent system that contained chloroform, methanol, acetic acid and water $(85: 22 \cdot 5: 10: 4$, v/v) (Torreblanca et al., 1986). Glycolipids were detected as purple spots by spraying with $0.5 \% \quad \alpha$-naphthol in methanol/water $(1: 1)$ and then with sulfuric acid/ethanol (1:1), followed by slight heating at $160{ }^{\circ} \mathrm{C}$. Other lipids were detected as brown spots after prolonged heating.

For extraction of genomic DNA and determination of DNA G $+\mathrm{C}$ content, cells were harvested, washed and suspended in $0 \cdot 15 \mathrm{M} \mathrm{NaCl} / 0 \cdot 1 \mathrm{M}$ EDTA buffer ( $\mathrm{pH} 8 \cdot 0$ ). Lysis was accomplished at $60{ }^{\circ} \mathrm{C}$ for $10 \mathrm{~min}$ by adding SDS at a final concentration of $2 \%(\mathrm{w} / \mathrm{v})$. DNA was extracted and purified by the method of Marmur (1961). Purity was assessed from $A_{260} / A_{280}$ and $A_{230} / A_{260}$ absorbance ratios (Johnson, 1994). DNA G $+\mathrm{C}$ content was determined from the mid-point value $\left(T_{\mathrm{m}}\right)$ of the thermal denaturation profile (Marmur \& Doty, 1962), which was obtained by using a Perkin-Elmer UV-Vis 551S spectrophotometer at
$260 \mathrm{~nm}$. This instrument was programmed for temperature increases of $1.0^{\circ} \mathrm{C} \mathrm{min}{ }^{-1}$. The $T_{\mathrm{m}}$ was determined by a graphic method described by Ferragut \& LeClerc (1976), and the G+C content was calculated from this temperature by using the equation of Owen \& Hill (1979), in $0 \cdot 1 \times$ SSC buffer $(0 \cdot 15 \mathrm{M} \mathrm{NaCl}$ buffered with $0 \cdot 015 \mathrm{M}$

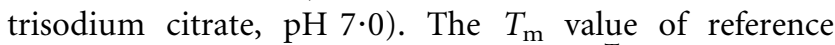
DNA from Escherichia coli NCTC $9001^{\mathrm{T}}$ was taken as $74 \cdot 6{ }^{\circ} \mathrm{C}$ in $0 \cdot 1 \times$ SSC (Owen \& Pitcher, 1985).

DNA was labelled by the multiprime system with a commercial kit with $\operatorname{deoxy}\left(1^{\prime}, 2^{\prime}, 5^{\prime}-{ }^{3} \mathrm{H}\right)$ cytidine $5^{\prime}$ triphosphate (Amersham Biosciences). The mean specific activity obtained with this procedure was $8.4 \times 10^{6}$ c.p.m. $(\mathrm{mg} D N A)^{-1}$. Labelled DNA was denatured before hybridization by heating at $100^{\circ} \mathrm{C}$ for $5 \mathrm{~min}$ and then placed on ice. DNA-DNA hybridization studies were performed by the competition procedure of the membrane method, as described by Johnson (1994). Competitor DNA was sonicated (B. Braun Melsungen) at $50 \mathrm{~W}$ for two intervals of $15 \mathrm{~s}$. Membrane filters (HAHY; Millipore) that contained reference DNA $\left(25 \mu \mathrm{g} \mathrm{cm}^{-2}\right)$ were placed in $5 \mathrm{ml}$ screw cap vials that contained labelled, sheared, denatured DNA and denatured, sheared competitor DNA. The ratio of the concentrations of competitor to labelled DNA was at least $150: 1$. The final volume and concentration were adjusted to $140 \mathrm{ml}, 2 \times$ SSC and $30 \%$ formamide. The hybridization temperature was $57^{\circ} \mathrm{C}$, which is within the limits of validity for the filter method (De Ley 
\& Tijtgat, 1970). Vials were shaken slightly for $18 \mathrm{~h}$ in a water bath; these procedures were done in triplicate. After hybridization, filters were washed in $2 \times$ SSC at the optimal renaturation temperature $\left(58^{\circ} \mathrm{C}\right)$. Radioactivity bound to the filters was measured in a liquid scintillation counter (Beckman) and relatedness (\%) was calculated according to Johnson (1994). At least two independent determinations were carried out for each experiment; reported results are mean values.

$16 \mathrm{~S}$ rRNA genes were amplified by PCR with a primer set [5'-ATTCCGGTTGATCCTGCCGG-3' (positions 6-25, according to E. coli numbering) and 5'-AGGAGGTGATCCAGCCGCAG-3' (positions 1540-1521)] by using Platinum Taq DNA Polymerase High Fidelity (Invitrogen). PCR products were cloned into the SmaI site of vector pUC119 and sequencing was carried out with a Beckman Coulter capillary DNA sequencer SEQ2000XL. 16S rDNA sequences were obtained from databases and aligned according to the Ribosome Database Project II. Tree reconstructions were performed by using the neighbour-joining and Kimura's two-parameter calculation methods.

Strains VKM B-1739, VKM B-1916, VKM B-1954 and VKM B-2151 are pleomorphic, motile, Gram-negative and able to grow in a wide range of salinities (15-30\% salt; optimal growth at $25 \%$ ). They lyse in distilled water. Colonies on solid media are orange-red-pigmented. Results of phenotypic tests and nutritional features of these strains are included in the species description. The polar lipid composition of these four strains are $\mathrm{C}_{20} \mathrm{C}_{20}$ derivatives of phosphatidylglycerol, phosphatidylglycerol phosphate methyl ester, phosphatidylglycerol sulfate and a sulfated diglycosyl diether, which has been shown to be a distinctive feature of species of the genus Halorubrum (McGenity \& Grant, 2001).

The DNA G $+\mathrm{C}$ content of the four strains studied ranged from $64 \cdot 2$ to $64 \cdot 9 \mathrm{~mol} \%$ (Table 1). This result is within the range of $\mathrm{G}+\mathrm{C}$ contents reported for the genus Halorubrum (McGenity \& Grant, 2001). The DNA G +C content of Halorubrum distributum VKM B-1733 ${ }^{\mathrm{T}}$ was $63.9 \mathrm{~mol} \%$, a very similar value to that reported previously $(63.6 \mathrm{~mol} \%)$ (McGenity \& Grant, 2001). Results of DNA-DNA hybridization experiments are shown in Table 1. High levels of relatedness were found between strain VKM B-1739 and the other three related strains (95-100\%); however, levels of DNA relatedness with the type strains of species of the genus Halorubrum, as well as other genera of the Halobacteriaceae, were $<70 \%$, which is the value that is currently accepted for the delineation of prokaryotic species (Stackebrandt \& Goebel, 1994).

The 16S rRNA gene sequence of strain VKM B-1739 was most closely related to those of Halorubrum coriense (97.1\% similarity) and Halorubrum distributum (97.0\% similarity). Fig. 1 shows a phylogenetic tree, in which the relationships of strain VKM B-1739 and other related halobacteria are seen. The 19 signature bases that are specific for the genus Halorubrum or are shared by only one other genus (Grant et al., 2001; Kamekura et al., 2004) were completely conserved.

Our results show that strains VKM B-1739, VKM B-1916, VKM B-1954 and VKM B-2151 are significantly different from other previously described species of the genus Halorubrum; on the basis of DNA-DNA hybridization data, as well as 16S rRNA gene sequence comparison, we propose to place these strains in a novel species, with the name Halorubrum terrestre sp. nov.

\section{Description of Halorubrum terrestre sp. nov.}

Halorubrum terrestre (ter.res' tre. L. neut. adj. terrestre of the soil, from which the strains were isolated).

Cells are pleomorphic, flat and disc-shaped, $1 \cdot 0-1 \cdot 5 \times 1 \cdot 5-$ $2.5 \mu \mathrm{m}$ in size. Motile. Gas vacuoles are not produced. Colonies are orange-red. Growth occurs in media that contain $15-30 \% \mathrm{NaCl}$, with optimum growth at $25 \%$ $\mathrm{NaCl}$. Growth occurs between 28 and $50{ }^{\circ} \mathrm{C}$ (optimum, 37$45^{\circ} \mathrm{C}$ ) and pH 5-9 (optimum, 7·5). Chemo-organotrophic. Aerobic. Oxidase- and catalase-positive. Acid is produced from glycerol, but not from arabinose, fructose, galactose, glucose, lactose, maltose, sucrose or trehalose. Nitrate is not reduced to nitrite. Indole is not produced from tryptophan. Voges-Proskauer test is negative. Starch, gelatin and casein are not hydrolysed. $\mathrm{H}_{2} \mathrm{~S}$ is not produced. Arginine dihydrolase, lysine decarboxylase and ornithine decarboxylase are not produced. The following compounds are not

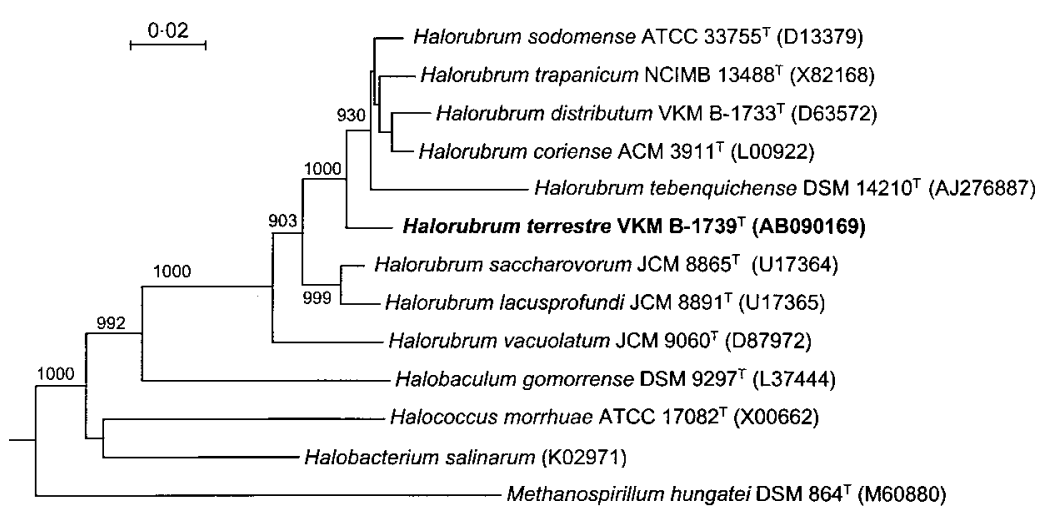

Methanospirillum hungatei DSM 864 ${ }^{\top}$ (M60880)
Fig. 1. Phylogenetic tree of strain VKM B-1739 and other related halobacterial species based on their 16S rRNA gene sequences (GenBank accession numbers are shown in parentheses). Numbers on branches represent confidence levels from 1000 replicate bootstrap resamplings; values $>70 \%$ are shown. Bar, 0.02 expected changes per site. 
used as sole carbon and energy sources: arabinose, cellobiose, aesculin, fructose, fucose, gluconolactone, glucose, glucosamine, inulin, mannose, melibiose, raffinose, rhamnose, ribose, sucrose, trehalose, xylose, adonitol, dulcitol, erythritol, ethanol, glycerol, mannitol, meso-inositol, propanol, sorbitol, $\alpha$-aminovalerate, butyrate, caprylate, citrate, fumarate, glutamate, glycerate, 2-oxoglutarate, malate, malonate, oxalate, propionate, saccharate and tartrate. The following compounds are not used as sole carbon, nitrogen or energy sources: L-alanine, L-arginine, L-asparagine, betaine, creatine, L-glutamine, glycine, L-histidine, L-lysine, L-methionine, L-ornithine, L-proline, putrescine, sarcosine, L-serine, L-threonine and L-valine. Susceptible to anisomycin, bacitracin and novobiocin; resistant to ampicillin, chloramphenicol, kanamycin, nalidixic acid, penicillin G, polymyxin, streptomycin and tetracycline. Polar lipids are $\mathrm{C}_{20} \mathrm{C}_{20}$ derivatives of phosphatidylglycerol, phosphatidylglycerol phosphate methyl ester, phosphatidylglycerol sulfate and a sulfated diglycosyl diether. DNA G $+\mathrm{C}$ content is $64 \cdot 2-64 \cdot 9 \mathrm{~mol} \%\left(T_{\mathrm{m}}\right.$ method).

Type strain is $4 \mathrm{p}^{\mathrm{T}}\left(=\mathrm{VKM} \mathrm{B}-1739^{\mathrm{T}}=\mathrm{JCM} 10247^{\mathrm{T}}\right)$. DNA $\mathrm{G}+\mathrm{C}$ content of this strain is $64 \cdot 4 \mathrm{~mol} \%$ ( $T_{\mathrm{m}}$ method). Isolated from saline soils.

\section{Acknowledgements}

We thank H. G. Trüper for his advice on nomenclature of the novel species. This work was supported by grants from the Quality of Life and Management of Living Resources Programme of the European Commission (QLK3-CT-2002-01972), Spanish Ministerio de Ciencia y Tecnología (PB98-1150 and BMC2003-01344) and from Junta de Andalucía (to A. V.).

\section{References}

De Ley, J. \& Tijtgat, R. (1970). Evaluation of membrane filter methods for DNA-DNA hybridization. Antonie van Leeuwenhoek 36, 461-474.

Ferragut, C. \& LeClerc, H. (1976). Étude comparative des méthodes de détermination du $T_{\mathrm{m}}$ de l'ADN bactérien. Ann Microbiol (Paris) 127A, 223-235 (in French).

Grant, W. D., Kamekura, M., McGenity, T. J. \& Ventosa, A. (2001). Class III. Halobacteria class. nov. In Bergey's Manual of Systematic Bacteriology, 2nd edn, vol. 1, pp. 294-301. Edited by D. R. Boone, R. W. Castenholz \& G. M. Garrity. New York: Springer.

Johnson, J. L. (1994). Similarity analysis of DNAs. In Methods for General and Molecular Bacteriology, pp. 655-682. Edited by P. Gerhardt, R. G. E. Murray, W. A. Wood \& N. R. Krieg. Washington, DC: American Society for Microbiology.

Kamekura, M. (1993). Lipids of extreme halophiles. In The Biology of Halophilic Bacteria, pp. 135-161. Edited by R. H. Vreeland \& L. I. Hochstein. Boca Raton, FL: CRC Press.

Kamekura, M. \& Dyall-Smith, M. L. (1995). Taxonomy of the family Halobacteriaceae and the description of two new genera Halorubrobacterium and Natrialba. J Gen Appl Microbiol 41, 333-350.

Kamekura, M., Mizuki, T., Usami, R., Yoshida, Y., Horikoshi, K. \& Vreeland, R. H. (2004). The potential utility of signature bases in the
$16 \mathrm{~S}$ rRNA gene sequences to aid in the definition of genera of halobacteria. In Halophilic Microorganisms, pp. 77-87. Edited by A. Ventosa. New York: Springer.

Lapage, S. P., Sneath, P. H. A., Lessel, E. F., Skerman, V. B. D., Seeliger, H. P. R. \& Clark, W. A. (editors) (1992). International Code of Nomenclature of Bacteria (1990 Revision). Bacteriological Code. Washington, DC: American Society for Microbiology.

Marmur, J. (1961). A procedure for the isolation of deoxyribonucleic acid from microorganisms. J Mol Biol 3, 208-218.

Marmur, J. \& Doty, P. (1962). Determination of the base composition of deoxyribonucleic acid from its thermal denaturation temperature. J Mol Biol 5, 109-118.

McGenity, T. J. \& Grant, W. D. (1995). Transfer of Halobacterium saccharovorum, Halobacterium sodomense, Halobacterium trapanicum NRC 34021 and Halobacterium lacusprofundi to the genus Halorubrum gen. nov., as Halorubrum saccharovorum comb. nov., Halorubrum sodomense comb. nov., Halorubrum trapanicum comb. nov., and Halorubrum lacusprofundi comb. nov. Syst Appl Microbiol 18, 237-243.

McGenity, T. J. \& Grant, W. D. (2001). Genus VII. Halorubrum. In Bergey's Manual of Systematic Bacteriology, 2nd edn, vol. 1, pp. 320-324. Edited by D. R. Boone, R. W. Castenholz \& G. M. Garrity. New York: Springer.

Oren, A. \& Ventosa, A. (1996). A proposal for the transfer of Halorubrobacterium distributum and Halorubrobacterium coriense to the genus Halorubrum as Halorubrum distributum comb. nov. and Halorubrum coriense comb. nov., respectively. Int J Syst Bacteriol 46, 1180 .

Oren, A., Kamekura, M. \& Ventosa, A. (1997a). Confirmation of strain VKM B-1733 as the type strain of Halorubrum distributum. Int $J$ Syst Bacteriol 47, 231-232.

Oren, A., Ventosa, A. \& Grant, W. D. (1997b). Proposed minimal standards for description of new taxa in the order Halobacteriales. Int J Syst Bacteriol 47, 233-238.

Owen, R. J. \& Hill, L. R. (1979). The estimation of base compositions, base pairing and genome size of bacterial deoxyribonucleic acids. In Identification Methods for Microbiologists, pp. 277-296. Edited by F. A. Skinner \& D. W. Lovelock. London: Academic Press.

Owen, R. J. \& Pitcher, D. (1985). Current methods for estimating DNA base composition and levels of DNA-DNA hybridization. In Chemical Methods in Bacterial Systematics, pp. 67-93. Edited by M. Goodfellow \& D. E. Minnikin. London: Academic Press.

Stackebrandt, E. \& Goebel, B. M. (1994). Taxonomic note: a place for DNA-DNA reassociation and 16S rRNA sequence analysis in the present species definition in bacteriology. Int J Syst Bacteriol 44, 846-849.

Torreblanca, M., Rodriguez-Valera, F., Juez, G., Ventosa, A., Kamekura, M. \& Kates, M. (1986). Classification of non-alkaliphilic halobacteria based on numerical taxonomy and polar lipid composition, and description of Haloarcula gen. nov. and Haloferax gen. nov. Syst Appl Microbiol 8, 89-99.

Zvyagintseva, I. S. \& Tarasov, A. L. (1987). Extreme halophilic bacteria from saline soils. Mikrobiologiya 56, 839-844 (in Russian).

Zvyagintseva, I. S. \& Tarasov, A. L. (1989). Halobacterium distributus sp. nov. In Validation of the Publication of New Names and New Combinations Previously Effectively Published Outside the IJSB, List no. 31. Int J Syst Bacteriol 39, 495-497; erratum 40, 106.

Zvyagintseva, I. S., Kudryashova, E. B. \& Bulygina, E. S. (1996). Proposal of a new type strain of Halobacterium distributum. Microbiology (English translation of Mikrobiologiya) 65, 352-354. 